\title{
Landfill NIMBY and Systems Engineering: A Paradigm for Urban Planning
}

\author{
G. Fred Lee, Ph.D., P.E., D.E.E. and Anne Jones-Lee, Ph.D. \\ G. Fred Lee \& Associates-EnviroQual \\ 27298 East El Macero Drive \\ El Macero, CA \\ Frederick Martin, MSPH, REA \\ E2C Incorporated \\ Sunnyvale, CA
}

\begin{abstract}
A solid waste management crisis exists in many parts of the US as a result of the inability to site new landfills to replace the consumed capacity of existing landfills. Municipal solid waste (MSW) landfills can, and usually do, have a significant adverse impact on the individuals who own property in, reside in, or otherwise use, areas near the landfill. This leads those who stand to be adversely affected by a landfill to take a justifiable "NIMBY" (Not in My Back Yard) position against it. In the past and even today the approach that is used for siting landfills is to select one or more specifically rural areas as candidate sites and then through a contrived process, force one or more of those sites on those who own or use nearby properties. If those in the potential sphere of influence of the landfill, which is often several miles from its location, are sufficiently politically powerful or have sufficient financial resources to actively oppose the siting of the landfill in their region, they can usually be successful in stopping the landfill from being sited in their area.
\end{abstract}

Some jurisdictions purport to involve the public in the site-selection process by appointing a "citizens advisory committee" (CAC). The CAC is then "allowed" to select and rank the parameters of concern with respect to the landfill. Based on an arbitrarily developed numeric scoring system, various potential candidate sites are ranked and those with the highest ranking are selected as the "best available sites." While the site-selection process and the design of the landfill should be coordinated and concurrent activities, they are typically pursued sequentially which contributes to the unreliability of the process. While this process appears superficially to have a technical aura about it, and public participation components in it, it is highly arbitrary and frequently capricious in its implementation. Rarely does this process lead to "the best available site" that would enable the development of a particular landfill at the particular location without a significant adverse impact on the current owners and users of nearby lands, future generations who may own or use those lands, and those who would use groundwaters hydraulically connected to the area at some time in the future.

There is need to take a significantly different approach to landfill siting than is being used today. Systems engineering provides a potential methodology for rigorous incorporation of the various factors that need to be considered in developing solid waste management capacity for a region. This paper reviews the issues of site selection for MSW management, legitimate NIMBY concerns, and how systems engineering could be used to more appropriately select a site/method for MSW management for a region.

\section{INTRODUCTION}

The acronym "NIMBY" ("Not in My Back Yard") arose to evoke the image of selfcentered citizens intent on preventing the siting of necessary and appropriate waste management or other facilities in their vicinity for little or no legitimate reason other than their personal preference. It is coming to be recognized, however, that such is often an unjustified characterization of citizens concerned about the protection of their health, environment, and economic welfare. Indeed, "NIMBYs" are becoming more educated and informed, grass-roots, political forces bringing changes in both the substance and 
process of urban planning; they have become a prominent force in many urban projects. NIMBYs are having an increasing influence on the management of municipal solid waste (MSW) owing largely to the fact that the interests of those who stand to be adversely affected by a landfill are not protected by the process of siting, evaluating, and developing waste management facilities. In this paper a systems engineering (SE) paradigm is formulated for urban planning incorporating the Citizen Advisory Committee (CAC) to represent the NIMBY force. The paradigm is illustrated with the issue of selecting a site for a landfill at which to dispose MSW.

\section{JUSTIFIABLE NIMBY}

Municipal solid wastes are principally generated in urban areas yet are typically disposed of in rural areas in landfills that proponents claim will not have adversely effects. If the landfills were in fact innocuous, there would be no need to find "less populated" areas for them. The reality is, however, that landfills of the type being developed today are not innocuous; they are known to cause a variety of aesthetic, environmental quality, and public health problems for those in their vicinity. The rationale of placing landfills in rural areas - to reduce the number of adversely affected people - is thus lost when consideration is given to the urban source of the waste, to the rights of the rural-property-dwellers/users to protection of their properties, health, and welfare, and to the type and degree of protection afforded by the landfilling regulations.

On October 9, 1991, the US EPA adopted Subtitle D regulations for MSW landfills that prescribe what may be referred to as "dry tomb" landfills (US EPA, 1991), an approach significantly different from the classical, unlined "sanitary" landfills used in the past. "Dry tomb" landfills are designed in concept to try to keep moisture out of the landfill and to keep the leachate ("garbage juice") generated in the landfill from polluting groundwaters in the vicinity of the landfill. Toward that end, Subtitle D regulations specify as a minimum a single-composite liner and a low-permeable cover for MSW landfills. In setting forth those regulations, the US EPA (1991) stated that one of the benefits of them was that they should facilitate the siting of new landfills. The Preamble to the Subtitle D regulations states under "Other Benefits,"

"First, EPA believes that the promulgation of federal municipal solid waste landfill criteria will increase public confidence that landfills are designed to protect human health and the environment. EPA believes that this increased confidence will reduce opposition to landfills and make the siting of new landfills less difficult."

However, the conceptual functioning of a "dry tomb" landfill - to keep the wastes isolated from groundwater - cannot be achieved with the minimum requirements and approaches being used for them. "Dry tomb" landfills will not protect the quality of groundwaters hydraulically connected to them, for as long as the wastes in the landfill represent a threat. Further, the Subtitle D regulations adopted address groundwater quality protection only for a short period of time compared to the time that the waste will represent a threat to groundwater quality; at best, the liners system specified in these regulations will only postpone groundwater pollution, it will not prevent it (see Lee and Jones-Lee, 1992; 1993a,b; Jones-Lee and Lee, 1993; and Lee and Jones, 1993).

Therefore, contrary to the US EPA's claims of benefits of the new regulations and the increased "public confidence" they were believed to foster, those regulations will not in any significant way, and should not, deter public opposition to proposed landfills that stand to adversely affect the use, enjoyment, and value of property, public welfare, public health, or other issues of concern to the public (Lee and Jones, 1991). They basically only address postponing groundwater pollution for a few tens of years and do not address many of the major issues that cause the people who own or otherwise use lands near a proposed landfill to justifiably oppose the landfill. 
The "bad neighbor" reputation of landfills was earned, in part, because those who generate the wastes placed in the landfills have not been asked, or required, to provide sufficient funds (e.g., in garbage disposal fees) to properly control many of the significant adverse impacts that are readily controllable in landfilling of MSW. As discussed by Lee and Jones-Lee (1994), most of the justifiable NIMBY that occurs today associated with the siting of new or expanded landfills can be readily addressed through adequate funding of appropriate solid waste management. It is well-known that the costs for attempting to rectify problems discovered with leaking landfills and to compensate for lost resources due to groundwater pollution by landfill leachate far-outweigh those associated with taking the steps necessary to ensure groundwater quality protection for as long as the wastes represent a threat, i.e., in perpetuity.

\section{ADVERSE IMPACTS OF "DRY TOMB" LANDFILLS ON PROPERTY OWNERS/USERS}

While the US EPA has stated that one of the benefits of the Subtitle D regulations will be reduced opposition to siting landfills, in fact, the Agency has not addressed many of the key issues that cause public opposition to particular landfills. As discussed by Lee and Jones-Lee (1993c; 1994), the wide variety of justifiable reasons for opposing landfills in the vicinity of a property, residence, or workplace include,

- public health, economic and aesthetic aspects of groundwater and surface water quality

- methane and VOC migration - public health hazards, explosions and toxicity to plants

- illegal roadside dumping and litter near landfill

- truck traffic

- noise

- dust and wind-blown litter

- odors

- vectors, insects, rodents, birds

- condemnation of adjacent/nearby property for future land uses
- decrease in property values

- impaired view-shed/aesthetics

- destruction of wildlife habitat

- destruction of archaeological sites

Many of the problems associated with landfills listed above, are related to problems during the active life of the landfill. As discussed by Lee and Jones-Lee (1993c; 1994), one of the most expedient ways that such problems can, in large part, be addressed in a rural setting is by providing an adequate landfill-owned land buffer between the landfill site and adjacent property owners' lands. The land buffer areas typically provided at landfills, however, are very limited, commonly a few hundred yards. The result is that those who own or use lands next to a landfill find that their use and enjoyment of these lands impaired because of the landfill. Any proposed landfill should have at least a mile or more of land between the active area of the landfill and adjacent property owners' lands. While it may be possible in some terrains to have smaller land buffers, in most cases even a one-mile land buffer will allow adverse impacts of a landfill on adjacent property owners/users due to truck traffic, illegal dumping, etc. Alternatively, substantial amounts of funds, effort, oversight, and public recourse would have to be provided to ensure that at the first occurrence of problems off-site, the facility would be closed permanently and the affected public appropriately compensated.

It is the authors' view that an equitable solution could be for anyone owning property within two miles of a proposed landfill to be given the option of selling their property to the landfill company/agency should they choose to do so, for at least the fair-market value. The value of the land should be based on its value prior to the proposal to develop a landfill in that area, and should reflect possible increased value that could otherwise occur over the next 10 years were it not for the placement of the landfill. It should be recognized, however, that some may not find this an equitable settlement, for example where loss of the land destroys a person's livelihood. 
One of the most significant consequences of the adoption of the "dry tomb" approach for managing MSW is that it perpetuates the garbage crisis that exists in the US, rather than address the issues contributing to the crisis in a committed, meaningful, technically reliable way so as to provide credible assurance to the people who reside on or otherwise use lands near a proposed landfill that the landfill will not represent a significant threat to their public health, groundwater resources, environmental quality, or social and economic welfare. The public will, with justification, continue to vigorously oppose "dry tomb" landfills that are to be sited in their vicinity until the issues are properly resolved, and the responsible commitment to that resolution is evidenced.

\section{UNRELIABLE APPROACHES FOR ADDRESSING LEGITIMATE NIMBY}

Today, some responsible for developing solid waste management capacity in particular jurisdictions are adopting public participation processes in which the public is ostensibly provided an opportunity to actively participate in site selection. Often this is done through a site-selection committee representing various interests in solid waste management in the area where the wastes are generated and in the areas where a landfill could be located. That committee develops a numeric site ranking procedure, under the guidance of the department of public works or some other entity responsible for solid waste management in the region. The committee identifies various criteria/issues of importance and then arbitrarily assigns a numeric value within a range of 1 to 10 to each of those criteria to represent the committee's consensus on its importance. Examples of such criteria include groundwater quality protection, solid waste transportation distance, significance of aboriginal artifacts, and various social/political/legal factors that could influence the siting of a landfill. The public works department then provides, sometimes blind, information on candidate sites within the region based on the information that is readily available on the characteristics of the areas. The selected potential sites are evaluated based on the criteria selected by the committee, and a "best possible" site(s) is selected.

Claims are made that this process is technically valid, unbiased, value-driven, well thought-out, rational, objective, and defensible, and that it "involves" the public in the decision-making process. The authors have been involved in reviews of such siteselection processes (Lee and Jones-Lee, 1993d) and have found that that type of siteselection process is typically technically invalid and can readily be manipulated to select for a particular site or group of sites. First, a critical aspect is the composition of the committee, itself. While purporting to be representative of the areas involved, rarely do such committees include a meaningful, influential representation of the individuals who actually stand to be adversely affected by the landfill at the various candidate sites. While those on the committee may have political, occupational, or other "interest" in the site selection, no interest is as intent on protecting the interests of those in need of protection than that of the public that stands to be affected.

Second, the authors have found that generally the committee does not have the expertise, and is not provided with appropriate independent expertise, to evaluate the technical validity or sufficiency of the information provided to it. For example, such committees often rank groundwater quality protection very high in site selection. However, at the time that the committee is selecting the "best possible site," there is commonly insufficient information available on the hydrogeological characteristics of the candidate sites to reliably evaluate and compare the sites for their natural ability to protect groundwater from leachate-pollution. There is also typically inadequate information to properly evaluate the ability of the "engineered" containment system - liners, etc. - to prevent groundwater pollution for as long as the wastes represent a threat. Absent such information and/or the ability to properly evaluate it, the committee is generally led to believe that the landfill that would be 
constructed at any of the sites would be protective of the groundwater resources of the region. However, understanding of the regulatory agency's minimum prescriptive standards (such as those of the US EPA Subtitle D requirements) for design, construction, operation, closure and postclosure care of landfills, and the associated funding requirements shows that the dry tomb landfill will do nothing more than postpone groundwater pollution.

Part of this "assurance" commonly comes from landfill proponents who often claim that the proposed landfill will meet or exceed regulatory requirements. However, what is not made clear to the committee is the fact that meeting or even exceeding inadequate prescriptive regulatory requirements does not provide assurance of protection of groundwater quality, public health, or welfare. At this time, few state regulatory agencies have requirements that in fact ensure a high degree of groundwater quality protection for as long as the MSW in the landfill represents a threat to groundwater quality. Even in those states such as California that have performance requirements that state that such protection shall be provided, the implementation of those requirements often falls far-short of achieving the performance standard. Thus, when the site-selection committee ranks groundwater quality protection as an area of great concern in landfill siting but has inadequate information and background, it assigns a numerical ranking for that criterion based on unsubstantiated, typically unreliable assurances that groundwater will be protected.

Also of concern in the site-selection process is the combining of scores for the various criteria in making the overall siteselection recommendations. For example, the committee numerically ranks its perception of the importance of not disturbing aboriginal artifacts, along with rankings of groundwater quality protection based on unreliable information (see Lee and Jones-Lee, 1993e). As discussed by Lee and Jones-Lee (1993d), it is inappropriate to give equivalent or comparative weight to the importance of future generations' groundwater resources and the potential presence of aboriginal culture remnant artifacts - on a scale of 1 to 10 or some other scale - contrived to yield a numeric score that can be mechanically plugged into the site-selection process.

The authors have frequently found that inadequate attention is given in the early phases of landfill site-selection to the longterm groundwater quality issues. Nevertheless, once the "best site" for the landfill has been selected by a committee using this process, it becomes very difficult, if not impossible, to acknowledge the shortcomings of, and errors made in, the siteselection, and to start over. While the arbitrarily developed numeric scoring and ranking procedure that is being used today to select sites for landfills gives the appearance of technical validity, objectivity, and public involvement, it is seriously flawed and is in many respects without technical justification. The selection of a site as the "best possible" site in such a process is often arbitrary, capricious, and certainly not well-thought-out, rational, objective, or defensible. In the absence of a disciplined methodology and technical support for thorough investigations, the CAC has insufficient capacity to obtain sound technical input; evaluate the technical data and analysis; assign meaningful priorities on the issues of groundwater, public health, environment, and community impact; assess the design parameters of a landfill that impact the critical issues; or make meaningful management and design tradeoffs.

Another significant problem with landfill site-selection committees is the way in which those responsible for site selection interact with the potentially impacted public. Previously, those responsible for developing solid waste management capacity would work behind the scenes until a site had been selected, then force that selection on property owners in the region. Today, the public (NIMBYs) have become sufficiently organized and effective so that they can, in many cases, block the siting of a landfill. This has led to attempts to involve the potentially impacted public in the decision- 
making process. With few exceptions, however, the authors have found that the socalled public involvement means that those potentially impacted are merely given the opportunity to express their views on why a landfill in their area is inappropriate. Rarely does such an expression result in any significant change in the landfill location or design. The landfill is still forced on those potentially impacted in the region where it will be sited. The potentially impacted public is rarely involved in the decision-making process in a meaningful way to ensure that the potential adverse impacts of the landfill are controlled and that appropriate compensation is made for the non-controllable impacts. As long as landfills are forced on people, there will be justifiable NIMBYs.

Lee and Jones-Lee (1994) discussed approaches that could potentially change "NIMBY" to "GIVE ME" through appropriate consideration and protection of the interests of those in the zone of influence of a proposed landfill. These include technically justifiable and achievable approaches with sufficient funding guarantees for preventing groundwater pollution at any time in the future, adequate land buffer zones, and appropriate financial compensation packages developed from increased garbage collection fees to compensate those in the sphere of influence of the landfill to enable them to readily leave the area or to accept the nonhealth and environmental impact-related effects of the landfill, such as altered/degraded view-shed.

\section{SYSTEMS ENGINEERING PARADIGM}

AB939, the California Integrated Solid Waste Management Act of 1989 (CA, 1989), was, in large part, the result of NIMBY politics. In this regard AB939 has four major thrusts: (1) diversion of 50\% of MSW from landfills into reuse, recycling and composting, (2) a local, pentannual review of MSW management by a local CAC to review the status of, and recommend revisions in, the management of MSW in the community, (3) provision for the siting and planning of new landfills with a 15-year horizon, (4) active management and operation of landfills to protect the public health with emphasis on post-closure requirements and activities. Thus, a major component of AB939 is the incorporation in MSW management and planning of active CAC to identify solid waste management issues; determine the regional need for solid waste collection systems, facilities, and market strategies for recyclable materials; facilitate multijurisdictional arrangements for marketing recyclable materials; facilitate resolution of conflicts and inconsistencies locally and in a multijurisdictional region; develop policies and procedures to guide the development of sites for processing and disposing of MSW, both locally and regionally.

The general public is becoming more involved, at least ostensibly, in the planning and management of MSW. However, managing MSW is an SE process that involves a host of technical, economic, and societal issues. From a SE perspective, can a role be defined for the CAC? Does it represent the customer and user of the system? Would it be part of the multidisciplinary team that assists and advises the systems engineer in managing the program? Is it integral to the SE process with authority on the level of the systems engineer? How is the public to be given an opportunity to exert an influence in the decisions regarding MSW management, beyond being tolerated by decision-making staff in "public hearings"? Beyond its pentannual cycle for review and analysis, how does it retain a consistent commitment to quality management of MSW?

\section{THE SE AND NIMBY PARADIGM}

In the management of MSW, and the siting and operation of an MSW landfill in particular, the SE process has six functions tailored to meet the needs of a CAC and the general requirements for the development and operation of a landfill, presuming appropriate representation of those within the sphere of landfill influence, on the CAC. As shown in Figure 1, these six functions, tailored so as to 
attach the CAC to the systems engineer, are (1) problem definition and system definition, (2) derived functional requirements, (3) key parameters and risks, (4) tradeoffs and synthesis into a pragmatic program, (5) Systems Analysis and control for overall objectives (the Engineer), (6) CAC.

Figure 1 shows the engineering process flowing from definition to synthesis under the control of the systems engineer, with the CAC as an adjunct to the engineer. By its nature the CAC suggests that it represents the customer, the user, and the public interest as a whole, as well as and especially those within the sphere of influence of the landfill whose public health, welfare, and resources stand to be adversely affected by it. On behalf of the public it has the basic task of setting standards, priorities, acceptable levels of risk, and arbitrates the jurisdictional conflicts and inconsistencies.

The process of developing a landfill for disposal of MSW has five stages in this paradigm (Figure 2). Although as noted earlier, post-closure activities are frequently ignored or, at best, vaguely acknowledged, they figure prominently in the mandates of AB939 and in the acquisition process. This importance has been recognized in Figure 2 by the division of the design stage into operations and post-closure design, with a feedback loop to the beginning of the process. Also indicated are major milestones and review in the acquisition process. It is critical that acquisition not go forward until there is a clear understanding of the site and its impact on the community during operation as well as in perpetuity after closure, and that the design and site-selection of a landfill must be concurrent, coordinated activities, not sequential ones.

Each stage of the acquisition involves the SE process of Figure 1. The CAC participates at each stage and shapes the process and design to try to ensure that all requirements affecting the public interest are satisfied. The CAC has a major role for public approval at the milestone for the review and acceptance of the proposed project and site. The CAC, representing the public interest as defined in AB939, needs to consider and evaluate a host of factors including: landfill design and alternatives, landfill operation, public health, air pollution, hydrogeology, use and potential future (ad infinitum) use of groundwaters hydraulically connected to the proposed landfill area, water pollution, natural habitat and open space, community impacts, site monitoring, post-closure use, and cost. It may not be possible to optimally satisfy all of these factors, but a landfill site is an ineluctable feature of our lifestyle so tradeoffs and adjustment to priorities with detailed assessments made on alternative technologies and sites, and compensation of those affected, will be a major effort for the engineers and the CAC. The methodology and practice of $\mathrm{SE}$ in the aerospace industry includes a number of tools for matching estimated system performance to the functional requirements. While these have not been applied in urban planning, one of the authors has illustrated their potential for such use (Martin, 1992, 1993). 


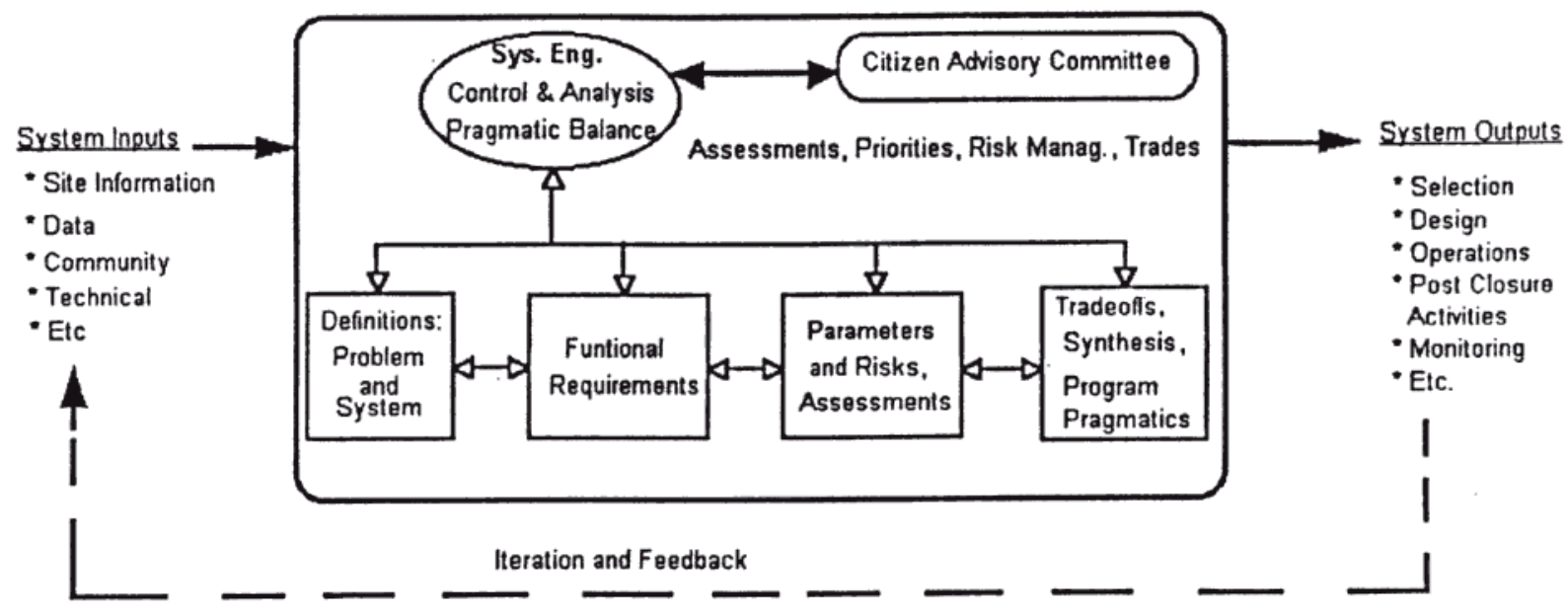

Figure 1. The Systems Engineering Process for Urban Planning Incorporating the NIMBY Issues

Principal Stages in the Acquisition, Operation and Post Operation of an MSW Landfill

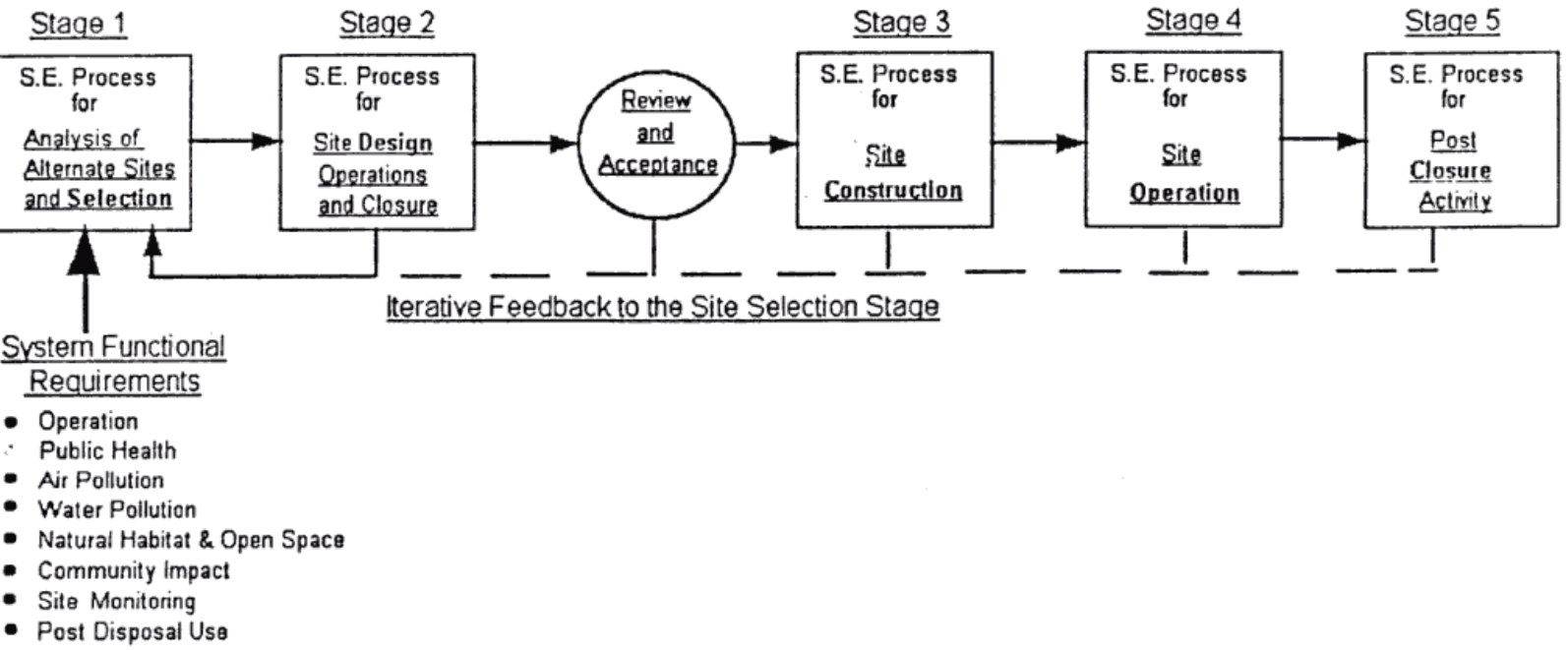

Figure 2. The Systems Engineering Process through Lifecycle of the Project 


\section{SUMMARY}

Very few communities have a comprehensive approach for evaluating and implementing a sound program for managing MSW. They often make a choice based on a perception of economic advantage of minimizing collection and "disposal" costs, and preconceived or induced impressions about the efficacy of a landfill with some recycling to meet their needs.

There is a serious lack of planning capability and understanding how to plan for complex systems such as defined by AB939. This paradigm for SE in MSW management provides a framework for filling that gap and truly involving public interests in the decision-making process. However, this process demands a high level of sophistication, education, and work on the part of the CAC, and a willingness of the decision-makers and engineers to give due consideration to the expressions of the CAC. Its success in resolving the NIMBY syndrome depends on the manner in which CAC's are constituted; the level of the CAC's understanding of the capabilities of the proposed landfill design, operation, maintenance, monitoring, closure and postclosure activities, and long-term funding for monitoring and remediation, to protect public health, groundwater resources, and environmental quality, as well as other potential adverse impacts of landfills; the level of influence given to the CAC; and the demonstrated commitment of CAC's to the protection, in perpetuity, of the interests of those who stand to be adversely affected by the particular landfill.

\section{REFERENCES}

CA, "State of California, Assembly Bill 939," Byron D. Sher, Assemblyman, District 21, Palo Alto, California, Approved by Governor September 29, 1989. Filed with Secretary of State September 30 (1989).

Jones-Lee, A., and Lee, G. F., "Groundwater Pollution by Municipal Landfills: Leachate Composition, Detection and Water Quality
Significance," Proceedings of Sardinia '93 IV International Landfill Symposium, Sardinia, Italy, October (1993).

Lee, G. F., and Jones, R. A., "Review of Proposed Landfills: Questions That Should Be Answered," Statement prepared by G. Fred Lee \& Associates, El Macero, CA, November (1991).

Lee, G. F., and Jones-Lee, A., "Municipal Landfill Post-Closure Care Funding: 30-Year Post Closure Care Myth," Report of G. Fred Lee \& Associates, El Macero, CA (1992).

Lee, G. F., and Jones, R. A., "Municipal Solid Waste Management in Lined, 'Dry Tomb' Landfills: A Technologically Flawed Approach for Protection of Groundwater Quality," Short-course notes for American Society of Civil Engineers short-course, New York City and Atlanta, GA, January (1993).

Lee, G. F., and Jones-Lee, A., "Landfill PostClosure Care: Can Owners Guarantee the Money Will Be There?" Solid Waste and Power ㄱ(4):35-39 (1993a).

Lee, G. F., and Jones-Lee, A., "Groundwater Quality Monitoring at Lined Landfills: Adequacy of Subtitle D Approaches," Report of G. Fred Lee \& Associates, El Macero, CA and short-course notes, Landfills and Groundwater Quality Protection Issues shortcourse, University of California, Riverside Extension, Riverside, CA, June (1993b).

Lee, G. F., and Jones-Lee, A., "Environmental Impacts of Alternative Approaches of Municipal Solid Waste Management: An Overview," Report of G. Fred Lee \& Associates, El Macero, CA, July (1993c).

Lee, G. F., and Jones-Lee, A., "Comments on Alachua Department of Public Works' Landfill Siting Process and Selection of Site E as Best Available Site for County Landfill," Report of G. Fred Lee \& Associates, El Macero, CA, July (1993d).

Lee, G. F., and Jones-Lee, A., "Practical Environmental Ethics: Is There an Obligation 
to Tell the Whole Truth?" Submitted to Civil Engineering, ASCE, May (1993e).

Lee, G. F., and Jones-Lee, A., "Addressing Justifiable NIMBY: A Prescription for MSW Management," Environmental Management Review, Government Institutes, Rockville, MD, No. 31, First Quarter, pp. 115-138 (1994).

Martin, F., "Using Systems Engineering to Evaluate Highway Alternatives," Public Works Magazine, p. 65, April (1992).

Martin, F., "Can Systems Engineering Save the Environment?," IN: Proceedings of the 1991 NCOSE Symposium, Chattanooga, Tennessee, October (1991), Reprinted in the Environment Monitor, Association of Environmental Professionals, Spring (1993).

US EPA, "Solid Waste Disposal Facility Criteria; Final Rule," 40 CFR Parts 257 and 258, Federal Register 56(196):50978-51119, October 9 (1991).

\section{AUTHORS' BIOGRAPHIES}

Drs. G. Fred Lee and Anne Jones-Lee are the principals of G. Fred Lee \& AssociatesEnviroQual, the firm through which they provide consulting services to governmental agencies, industry, environmental groups, and others. Dr. Lee's background is principally in environmental engineering, aquatic chemistry, and public health. He holds a PhD degree from Harvard University in environmental engineering and environmental sciences, and an MS Public Health degree from the University of North Carolina. Dr. Jones-Lee's background is aquatic toxicology and aquatic biology. She earned her PhD degree in environmental science from the University of Texas at Dallas. The focus of their work is the evaluation and management of impacts of chemical contaminants on water quality, aquatic life, and public health; they have extensive experience in issues of the impacts of hazardous and municipal solid waste management on public health and groundwater quality. Dr. Lee is frequently a reviewer of proposed landfill design, operation, closure, and post-closure activities relative to groundwater quality protection. They frequently present lectures, short-courses, workshops, and conference sessions in these areas, and have published more than 650 professional papers and reports. Dr. Lee is a registered professional engineer in Texas and a Diplomate in the American Academy of Environmental Engineers.

Frederick Martin received an MS degree in physics from the University of California at Berkeley, and an MS degree in physics from California Institute of Technology. He was an experimental physicist at Stanford Linear Accelerator Center, and a systems engineer at GTE. He is currently an environmental systems consultant at E2C, Inc., an environmental consulting firm in Sunnyvale, CA. Mr. Martin is a member of IEEE and a Registered Environmental Assessor in California. He holds 5 patents and authored more than 40 papers and presentations in technical journals or meetings, several of which address the application of Systems Engineering to environmental management.

Published in Proceedings of National Council on Systems Engineering Fourth Annual International Symposium, "Systems Engineering: A Competitive Edge in a Changing World," San Jose, CA, Vol. 1, pp. 991-998, August (1994). 